\title{
Study on the Synthesis and Transformations of some Substituted 4-methylquinolin-2(1H)-ones
}

\author{
Le The Duan ${ }^{2}$, Nguyen Dinh Thanh ${ }^{1, *}$ \\ Nguyen Thi Thanh ${ }^{2}$, Hoang Thai $\mathrm{Vu}^{2}$, Nguyen Thi Minh Nguyet ${ }^{2}$, \\ Le Thi Hoai ${ }^{2}$, Nguyen Thi Thu $\mathrm{Ha}^{2}$, Tran Thi Thanh Van ${ }^{2}$ \\ ${ }^{1}$ High School for Gifted Students, VNU University of Science, 182 Luong The Vinh, Hanoi, Vietnam \\ ${ }^{2}$ Faculty of Chemistry, VNU University of Science, 19 Le Thanh Tong, Hanoi, Vietnam \\ Received 08 May 2017 \\ Revised 15 October 2017, Accepted 26 October 2017
}

\begin{abstract}
Some different substituted 4-methylquinolin-2(1H)-ones have been synthesized by closing corresponding (un)substituted acetoacetanilides in the presence of ionic liquid [Bmim] $\mathrm{BH}$. Obtained quinolines were converted to its 2-chloro derivatives by reaction with $\mathrm{POCl}_{3}$. Some compounds of substituted tetrazolo[1,5-a]quinolines were synthesized by reacting these 2-chloro derivatives with sodium azide in DMF as solvent. The structures of obtained compounds have been confirmed using spectroscopic methods (IR, NMR and MS).
\end{abstract}

Keywords: Knorr synthesis, 4-methylquinolin-2(1H)-ones, ionic liquid, sodium azido.

\section{Introduction}

Quinolones present in molecular skeleton of quinolone antibiotics, which are currently used in disease treatments [1], and is the most consumed antibacterial quinolone worldwide [2]. Of the quinolones, quinolin-2(1H)-ones have been synthesized [3], but its 2-chloro derivatives have not been studied much. On the other hand, the ionic liquids have been recently prepared and studied to use in many different chemical processes [4]. Herein, we report some study results about the synthesis and transformations of substituted 4-

\footnotetext{
*Corresponding author. Tel.: 84-904204799.

Email: nguyendinhthanh@hus.edu.vn

https://doi.org/10.25073/2588-1140/vnunst.4455
}

methylquinolin-2(1H)-ones from corresponding (un)substituted anilines and ethyl acetoacetate.

\section{Experimental Section}

Melting points were determined by open capillary method on STUART SMP3 instrument (BIBBY STERILIN, UK) and are uncorrected. IR spectra $(\mathrm{KBr}$ disc $)$ were recorded on an Impact 410 FT-IR Spectrometer (Nicolet, USA), ${ }^{1} \mathrm{H}$ and ${ }^{13} \mathrm{C}$ NMR spectra were recorded on Avance Spectrometer AV500 (Bruker, Germany) at $500 \mathrm{MHz}$ and 125.8 $\mathrm{MHz}$, respectively, using DMSO- $d_{6}$ as solvent and TMS as internal standard. Analytical thinlayer chromatography (TLC) was performed on silica gel $60 \mathrm{WF}_{254} \mathrm{~S}$ (Merck, Germany), 1Butyl-3-methylimidazolium hydroxide, [Bmim] $\mathrm{OH}$, was prepared by our method [5]. 
2.1. General procedure for synthesis of substituted 4-methylquinolin-2(1H)-ones (3a-h)

To a mixture of appropriate (un)substituted anilines (1b-d, $0.1 \mathrm{~mol}$ ), ethyl acetoacetate $(15.1 \mathrm{ml}, 0.12 \mathrm{~mol})$ in $100-\mathrm{ml}$ one-necked round-bottomed flask $0.2 \mathrm{ml}$ of [Bmim] $\mathrm{OH}$ was added. After that, xylene $(15 \mathrm{ml})$ was added to the reaction mixture while shaking well. A single distillation apparatus was set up and the distillation was carried out slowly and carefully for about 120 minutes to remove ethanol that was created in reaction. Then, the solvent xylene was removed by rotating distillation under reduced pressure. The residue, namely

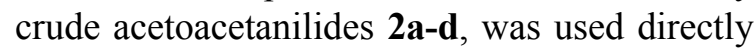
to ring close to quinoline-2 $(1 H)$-ones 3a-d.

To the above obtained residue in a $100-\mathrm{ml}$ one-necked round-bottomed flask, $30 \mathrm{ml}$ of $70-72 \% \quad \mathrm{H}_{2} \mathrm{SO}_{4} \quad\left(\mathrm{~d}=1.72 \mathrm{~g} / \mathrm{cm}^{3}\right)$ was added while stirring well. Then, the reaction mixture was heated carefully on the water bath at $90^{\circ} \mathrm{C}$. The smoke formed at this temperature indicated that the reaction began. After the release of smoke was diminished and the reaction mixture was no longer bubbling gas anymore, the mixture was heated at $95^{\circ} \mathrm{C}$ for about 30 minutes. The mixture was cooled to about $60^{\circ}$ $\mathrm{C}$ and poured carefully into $300 \mathrm{~g}$ of crushed ice, then filtered the precipitate, washed well with cold water to $\mathrm{pH} 7$ acid, and crystallized from $96 \%$ ethanol to efford the products 3a-d.

3a, $\mathbf{R}=\mathbf{H}$ : White solid, yield $78 \%, \mathrm{mp}$ $221-223^{\circ} \mathrm{C}$. IR $(\mathrm{KBr}), v\left(\mathrm{~cm}^{-1}\right): 3105,2914$, $2815,2723,1659,1544,1503,1431,1388 .{ }^{1} \mathrm{H}$ NMR (500.13 MHz, DMSO- $\left.d_{6}\right), \delta$ (ppm): 11.58 (s, 1H, NH lactam), 7.71 (dd, 1H, $J=1.0,8.0$ Hz. H-8), 7.50 (td. 1H. $J=1.0,8.0 \mathrm{~Hz}, \mathrm{H}-7$ ), 7.31 (dd, $1 \mathrm{H}, J=1.0,8.0 \mathrm{~Hz}, \mathrm{H}-5), 7.20$ (td, $J$ $=1.0,8.0 \mathrm{~Hz}, 1 \mathrm{H}, \mathrm{H}-6), 2.42(\mathrm{~d}, 1 \mathrm{H}, J=1.5 \mathrm{~Hz}$, 4-Me), ${ }^{13} \mathrm{C}$ NMR $\left(125.75 \mathrm{MHz}\right.$, DMSO- $\left.d_{6}\right), \delta$ (ppm): 162.11 (C-2), 148.42 (C-4), 139.10 (C8a), 130.75 (C-7), 125.19 (C-5), 122.13 (C-6), 121.29 (C-3), 120.06 (C-4a), 115.88 (C-8), 18.91 (4-Me). 3b, R=6-Me: White solid, yield $71.9 \%, \mathrm{mp}$ $188-190^{\circ} \mathrm{C}$. IR $(\mathrm{KBr}) \vee\left(\mathrm{cm}^{-1}\right): 3429,3150$, 2843, 1654, 1554, 1496, 1424, 1377.

3c, $\mathbf{R}=7-M e:$ White solid, yield $87.9 \%$, $\mathrm{mp}$ $175-177^{\circ} \mathrm{C}$. IR $(\mathrm{KBr}) \vee\left(\mathrm{cm}^{-1}\right): 3280,3155$, 2999, 2866, 1663, 1560, 1497, 1420, 1374.

3d, $\mathbf{R}=\mathbf{8}$-Me: White solid, yield $75.1 \%, \mathrm{mp}$ $178-180^{\circ} \mathrm{C}$. IR $(\mathrm{KBr}) \vee\left(\mathrm{cm}^{-1}\right): 3414,3279$, 3073, 2893, 1661, 1546, 1490, 1406, 1390. ${ }^{1} \mathrm{H}$ NMR (500.13 MHz, DMSO- $\left.d_{6}\right) \delta(\mathrm{ppm}): 11.50$ $(\mathrm{s}, 1 \mathrm{H}, \mathrm{NH}), 7.59(\mathrm{~d}, 1 \mathrm{H}, J=8.0 \mathrm{~Hz}, \mathrm{H}-5), 7.10$ (s, 1H, H-3), 7.03 (dd, 1H, $J=1.0,8.0 \mathrm{~Hz}, \mathrm{H}-$ 6), $6.31(\mathrm{~d}, 1 \mathrm{H}, J=1.0 \mathrm{~Hz}, \mathrm{H}-8), 2.39$ (d, 3H, $J$ $=1.0 \mathrm{~Hz}, 4-\mathrm{Me}), 2.37(\mathrm{~s}, 3 \mathrm{H}, 7-\mathrm{Me}),{ }^{13} \mathrm{C} \mathrm{NMR}$ $\left(125.75 \mathrm{MHz}, \mathrm{DMSO}-d_{6}\right) \delta(\mathrm{ppm}): 162.26$ (C2), 148.26 (C-4), 140.73 (C-8a), 139.25 (C-7), 125.05 (C-6), 123.49 (C-5), 120.29 (C-3), 118.96 (C-4a), 115.63 (C-8), 21.68 (7-Me), 18.87 (4-Me),

3e, $\mathbf{R}=\mathbf{6 , 8 - d i M e : ~ W h i t e ~ s o l i d , ~ y i e l d ~} 48.8 \%$,

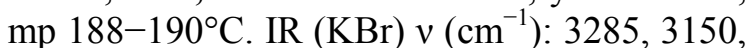
2890, 2866, 1665, 1560, 1497, 1420, 1374. ${ }^{1} \mathrm{H}$ NMR (500.13 MHz, DMSO- $\left.d_{6}\right), \delta(\mathrm{ppm})$ : Amide tautomer: $8.07(\mathrm{~s}, 1 \mathrm{H}, \mathrm{OH}), 7.62(\mathrm{~s}, 1 \mathrm{H}$, H-5), 7.52 (s, 1H, H-7), 7.43 (d, $1 \mathrm{H}, J=0.5 \mathrm{~Hz}$, $\mathrm{H}-3), 2.65(\mathrm{~d}, 3 \mathrm{H}, J=0.5 \mathrm{~Hz}, 4-\mathrm{Me}), 2.62(\mathrm{~s}$, $3 \mathrm{H}, \quad 6-\mathrm{Me}), 2.51$ (s, 3H, 8-Me); Iminol tautomer: 12,17 (s br, $1 \mathrm{H}, \mathrm{NH}), 7.72(\mathrm{~s}, 1 \mathrm{H}, \mathrm{H}-$ 5), 7.64 (s, 1H, H-7), 7.00 (s, 1H, H-3), 2.49 (s, $3 \mathrm{H}, 4-\mathrm{Me}), 2.23$ (s, 3H, 6-Me), 2.22 (s, 3H, 8Me). ${ }^{13} \mathrm{C}$ NMR $\left(125.75 \mathrm{MHz}\right.$, DMSO- $\left.d_{6}\right), \delta$ (ppm): Amide tautomer: 148.7 (C-2), 136.6 (C-4), 135.4 (C-8a), 128.4 (C-6), 127.2 (C-8), 122.5 (C-3), 122.2 (C-5 \& C-7), 20.8 (6-Me), 18.7 (8-Me), 18.4 (4-Me), Iminol tautomer: 153.6 (C-2), 148.2 (C-8a), 136.1 (C-4), 133.2 (C-8), 132.0 (C-7), 131.2 (C-5), 127.0 (C-6 \& C-7), 121.7 (C-3), 21.8 (6-Me), 18.4 (4-Me), 18.1 (8-Me),

3f, $\mathbf{R}=\mathbf{6 - O M e : ~ W h i t e ~ s o l i d , ~ y i e l d ~ 5 9 . 8 \% , ~}$ $\mathrm{mp} 257-259^{\circ} \mathrm{C}$. IR $(\mathrm{KBr}) v\left(\mathrm{~cm}^{-1}\right): 3155,2991$, 2855, 1658,1619, 1550, 1497, 1420, 1373.

3g, $\mathbf{R}=7-$-OMe: White solid, yield 75.1\%, mp 263-265 ${ }^{\circ} \mathrm{C}$. IR $(\mathrm{KBr}) \vee\left(\mathrm{cm}^{-1}\right): 3247,2953,2827$, $1655,1610,1549,1500,1490,1413,1390$. 
3h, R=6-OEt: White solid, yield $57.7 \%$, mp 259-261 ${ }^{\circ} \mathrm{C}$. IR $(\mathrm{KBr}) \vee\left(\mathrm{cm}^{-1}\right): 3155,2991$, 2855, 1670,1619, 1550, 1497, 1390. ${ }^{1} \mathrm{H}$ NMR $(500.13 \mathrm{MHz}$, DMSO-d 6 ), $\delta$ (ppm): Amide tautomer: $11,46(\mathrm{~s}, 1 \mathrm{H}, \mathrm{NH}), 7,85(\mathrm{~d}, 2 \mathrm{H}, J=$ 9,0, H-8), 7,44 (dd, 2H, $J=2,75,9,25 \mathrm{~Hz}, \mathrm{H}-7$ ), $7,42$ (s, 2H, H-3), 7,33 (d, 2H, $J=2,5 \mathrm{~Hz}, \mathrm{H}-5)$, $4,42\left(\mathrm{q}, 4 \mathrm{H}, J=7,0 \mathrm{~Hz}, 2 \times 6-\mathrm{OCH}_{2} \mathrm{CH}_{3}\right), 2,65$ (s, 6H, 4-Me $\times 2), 1,42(\mathrm{t}, 6 \mathrm{H}, J=7,0 \mathrm{~Hz}, 2 \times 6-$ $\left.\mathrm{OCH}_{2} \mathbf{C H}_{3}\right)$, Iminol tautomer: $\left(\delta_{\mathrm{OH}}\right.$ absent due to trace of water in solvent DMSO- $\left.d_{6}\right), 7.25$ (d, $1 \mathrm{H}, J=9.0 \mathrm{~Hz}, \mathrm{H}-8), 7.16(\mathrm{dd}, 1 \mathrm{H}, J=2.5,9.0$ Hz, H-7), 7.12 (d, 1H, $J=2.0 \mathrm{~Hz}, \mathrm{H}-5), 6.38$ (s, $1 \mathrm{H}, \mathrm{H}-3), 4.08$ (q, 2H, $J=7.0 \mathrm{~Hz}, 6-$ $\left.\mathrm{OCH}_{2} \mathrm{CH}_{3}\right), 2.40$ (s, 3H, 4-Me), 1.35 (t, 3H, $J=$ 7.0 Hz, 6-OCH $\left.\mathbf{C H}_{3}\right) \cdot{ }^{13} \mathrm{C}$ NMR $(125.75 \mathrm{MHz}$, DMSO- $\left.d_{6}\right), \delta$ (ppm): Amide tautomer: 157.4 (C-2 \& C-6), 147.9 (C-4), 130.3 (C-4a \& C8a), 123.0 (C-8), 122.7 (C-3), 119.8 (C-7), 104.2 (C-5), 64.1 (2×6-OCH $\left.\mathrm{CH}_{3}\right), 18.6$ $\mathrm{Me}), 15.0 \quad\left(6-\mathrm{OCH}_{2} \mathbf{C H}_{3}\right)$, Iminol tautomer: 161.6 (C-2), 153.8 (C-6), 147.4 (C-4), 143.1 (C-8a), 133.5 (C-8), 128.3 (C-7), $121.7 \quad$ (C4a), 120.7 (C-7), 117.1 (C-3), 108.1 (C-5), $64.0 \quad\left(6-\mathrm{OCH}_{2} \mathrm{CH}_{3}\right), 19.0 \quad$ (4-Me), $15.1 \quad$ (6$\left.\mathrm{OCH}_{2} \mathbf{C H}_{3}\right)$.

2.2. General procedure for synthesis of substituted 2-chloro-4-methylquinolines (4a-d)

To the appropriate (un)substituted 4methylquinolin-2(1H)-one (3a or $\mathbf{3 b}$-d, 0.02 $\mathrm{mol})$, in $50-\mathrm{ml}$ one-necked flask was added freshly distilled phosphoryl chloride $(8 \mathrm{ml})$ and shaked the mixture well. Heated the reaction mixture on water at $70^{\circ} \mathrm{C}$ until the solid dissolved completely, and then $1 \mathrm{~h}$ more. Cooled the reaction mixture to room temperature, and poured slowly and carefully into $300 \mathrm{~g}$ of crushed ice while stirring well (noted that crushed ice remained in the mixture to ensure the temperature was not over $20^{\circ} \mathrm{C}$ in this process), then neutralised the solution with $4 \mathrm{M}$ sodium hydroxide to $\mathrm{pH} 7$, and allowed to stand overnight. Checked the $\mathrm{pH}$ of the solution, if the $\mathrm{pH}$ decreased, then $\mathrm{NaOH}$ solution was added until neutral $\mathrm{pH}$ is reached. Filtered the precipitate separated, carefully rinsed with cold water until neutral $\mathrm{pH}$. Crystallized from $96 \%$ ethanol to yield products 4a-d as white powder.

4a, $\mathbf{R = H}$ : Opaque white solid, yield $89.2 \%$, mp 51-52 ${ }^{\circ} \mathrm{C}$. IR $(\mathrm{KBr}) \vee\left(\mathrm{cm}^{-1}\right): 3286,3057$, 2933, 2871, 1581, 1552, 1500, 1439, 1390. ${ }^{1} \mathrm{H}$ NMR (500.13 MHz, DMSO- $d_{6}$ ), $\delta$ (ppm): 8.01 (d, $1 \mathrm{H}, J=8.25 \mathrm{~Hz}, \mathrm{H}-8), 7.96(\mathrm{~d}, 1 \mathrm{H}, J=7.25$ Hz, H-5), 7.72 (td, 1H, $J=1.0,7.25 \mathrm{~Hz}, \mathrm{H}-6)$, $7.58(\mathrm{td}, 1 \mathrm{H}, J=1.0,8.25 \mathrm{~Hz}, \mathrm{H}-7), 7.25(\mathrm{~s}$, 1H, H-3), 2.69 (s, 3H, 4-Me). ${ }^{13} \mathrm{C}$ NMR (125.75 MHz, DMSO- $\left.d_{6}\right), \delta$ (ppm): 150.6 (C-2), 147.7 (C-4), 147.6 (C-8a), 130.3 (C-7), 129.2 (C-8), 127.0 (C-4a), 126.7 (C-6), 123.8 (C-5), 122.5 (C-3), 18.6 (4-Me). ESI-MS, $\quad m / z \quad(\%)$ : $180\left([\mathrm{M}+2+\mathrm{H}]^{+}, 31\right), 178\left([\mathrm{M}+\mathrm{H}]^{+}, 100\right), 183(5)$, 157(15), 142(15), 120(20), 106(10), 79(20).

4b, $\mathbf{R}=6-\mathrm{Me}$ : Pale brown solid, yield $96.1 \%, \mathrm{mp} 98-100^{\circ} \mathrm{C}$. IR $(\mathrm{KBr}) \vee\left(\mathrm{cm}^{-1}\right)$ : 3153 , $3059,2915,2852,1558,1501,1435,1376 .{ }^{1} \mathrm{H}$ NMR (500.13 MHz, $\left.\mathrm{CDCl}_{3}\right), \delta(\mathrm{ppm}): 7.90(\mathrm{~d}$, $1 \mathrm{H}, J=8.5 \mathrm{~Hz}, \mathrm{H}-8$ ), 7.71 (pseudo-singlet, $1 \mathrm{H}$, H-5), 7.55 (dd, $1 \mathrm{H}, J=1.5,8.5 \mathrm{~Hz}, \mathrm{H}-7$ ), 7.21 (s, 1H, H-3), 2.66 (s, 3H, 6-Me), 2.56 (s, 3H, 4$\mathrm{Me}),{ }^{13} \mathrm{C}$ NMR $\left(125.75 \mathrm{MHz}, \mathrm{CDCl}_{3}\right), \delta(\mathrm{ppm})$ : 149.6 (C-2), 147.0 (C-4), 146.1 (C-8a), 136.7 (C-6), 132.4 (C-7), 128.8 (C-8), 126.9 (C-4a), 122.9 (C-5), 122.4 (C-3), 21.8 (6-Me), 18.6 (4Me). ESI-MS, $m / z(\%): 194\left([\mathrm{M}+2+\mathrm{H}]^{+}, 30\right)$, 192([M+H $\left.]^{+}, 100\right), 179(5), 174(10), 163(10)$, 157(15), 142(5), 120(5).

4c, $\mathbf{R}=\mathbf{8}$-Me: Pale brown solid, yield $86.1 \%, \mathrm{mp} 92-93^{\circ} \mathrm{C}$. IR (KBr) $v\left(\mathrm{~cm}^{-1}\right): 3107$, 3013, 2956, 2837, 1591, 1426,1488, 1393.

4d, $\mathbf{R}=6$-OMe: Grey-brown solid, yield $96.2 \%, \mathrm{mp} 130-132^{\circ} \mathrm{C}$. IR $(\mathrm{KBr}) v\left(\mathrm{~cm}^{-1}\right): 3026$, 2930, 2836, 1591, 1563, 1490, 1429, 1390.

2.3. General procedure for synthesis of substituted 5-methyltetrazolo[1,5-a]quinolines $(5 a, b, f)$

To the mixture consisting of (un)substituted 2-chloro-4-methylquinolin $\mathbf{4 a}, \mathbf{4 b}$ or $\mathbf{4 f}, 1$ mmol) and sodium azide $(1,5 \mathrm{mmol})$ in $50 \mathrm{ml}$ of anhydrous DMF, a few crystals of KI was added. Shaked the reaction mixture well and 
then heated on water bath at $75-80^{\circ} \mathrm{C}$ for 12 hours. The solvent was removed by distillation under reduced pressure. Water (about $50 \mathrm{ml}$ ) was added to the residue in order to dissolve inorganic salts. Precipitate was filtered, washed well with water, and crystallized from $96 \%$ ethanol with activated charcoal to obtain corresponding 5-methyltetrazolo[1,5a] quinolines $\mathbf{5 a}, \mathbf{5 b}$ or $\mathbf{5 f}$.

5a, $\mathbf{R}=\mathbf{H}$ : Pale beige solid, yield $71.9 \%, \mathrm{mp}$ 199-200 ${ }^{\circ} \mathrm{C}$. IR $(\mathrm{KBr}) \vee\left(\mathrm{cm}^{-1}\right): 1620,1564$, 1500, 1449, 1373. ${ }^{1} \mathrm{H}$ NMR $(500.13 \mathrm{MHz}$, DMSO- $\left.d_{6}\right) \delta(\mathrm{ppm}): 8.84(\mathrm{~d}, 1 \mathrm{H}, J=7.5 \mathrm{~Hz}, \mathrm{H}-$ 9), $8.63(\mathrm{~d}, 1 \mathrm{H}, J=8.0 \mathrm{~Hz}, \mathrm{H}-6), 7.99-7.98$ (m, 1H, H-8), 7.96 (s, 1H, H-4), $7.85(\mathrm{t}, 1 \mathrm{H}, J=$ $7.25 \mathrm{~Hz}, \mathrm{H}-7), 2.75(\mathrm{~s}, 3 \mathrm{H}, 5-\mathrm{Me}) \cdot{ }^{13} \mathrm{C} \mathrm{NMR}$ (125.75 MHz, DMSO- $\left.d_{6}\right) \delta(\mathrm{ppm}): 147.3(\mathrm{C}-3)$, 142.7 (C-1), 131.8 (C-5), 130.2 (C-8), 128.5 (C-7), 126.9 (C-6), 124.4 (C-10), 116.9 (C-9) và $111.5(\mathrm{C}-4), 19.5(5-\mathrm{Me})$.

5b, R=7-Me: White crystal, yield 58.6\%, mp 98-99 ${ }^{\circ} \mathrm{C}$. IR $(\mathrm{KBr}) \vee\left(\mathrm{cm}^{-1}\right): 1635,1565$, 1510, 1450, 1373. ${ }^{1} \mathrm{H}$ NMR $(500.13 \mathrm{MHz}$, DMSO- $\left.d_{6}\right) \delta(\mathrm{ppm}): 7.80(\mathrm{~d}, 1 \mathrm{H}, J=8.5 \mathrm{~Hz}, \mathrm{H}-$ 9), 7.84 (s, 1H, H-4), 7.62 (dd, $1 \mathrm{H}, J=1.75,8.5$ $\mathrm{Hz}, \mathrm{H}-8), 7.38$ (d, 1H, $J=1.75 \mathrm{~Hz}, \mathrm{H}-6), 2.63$ (d, 3H, $J=1.0 \mathrm{~Hz}, 5-\mathrm{Me}), 2.51$ (s, 3H, 7-Me). ${ }^{13} \mathrm{C}$ NMR $\left(125.75 \mathrm{MHz}\right.$, DMSO- $\left.d_{6}\right) \delta$ (ppm): 149.1 (C-3), 148.5 (C-1), 145.9 (C-4), 137.1 (C-7), 133.0 (C-8), 128.5 (C-9), 127.0 (C-10), 123.8 (C-6), 122.5 (C-4), 18.4 (5-Me), 21.7 (7-Me),

5f, $\mathbf{R}=\mathbf{6 - O M e : ~ W h i t e ~ s o l i d , ~ y i e l d ~} \mathbf{9 0 \%}, \mathrm{mp}$ $150-151^{\circ} \mathrm{C}$. IR $(\mathrm{KBr}) \vee\left(\mathrm{cm}^{-1}\right): 1630,1574$, 1503, 1460, 1377. ${ }^{1} \mathrm{H}$ NMR $(500.13 \mathrm{MHz}$, DMSO- $\left.d_{6}\right) \delta(\mathrm{ppm}): 7.84(\mathrm{~d}, 1 \mathrm{H}, J=9.0 \mathrm{~Hz}, \mathrm{H}-$ 9), 7.44 (dd, $1 \mathrm{H}, J=9.0,3.0 \mathrm{~Hz}, \mathrm{H}-8), 7,41$ (d, $1 \mathrm{H}, J=0.5 \mathrm{~Hz}, \mathrm{H}-4), 7.33(\mathrm{~d}, 1 \mathrm{H}, J=3.0 \mathrm{~Hz}$, H-6), 3.94 (s, 3H, 7-OMe), 2.65 (d, 3H, $J=0.5$ $\mathrm{Hz}, 5-\mathrm{Me}) .{ }^{13} \mathrm{C}$ NMR $\left(125.75 \mathrm{MHz}, \mathrm{DMSO}-d_{6}\right)$ $\delta$ (ppm): 158.1 (C-7), 147.9 (C-3), 147.4 (C-1), 143.2 (C-5), 130.3 (C-9), 128.2 (C-10), 122.9 (C-8), 122.7 (C-4), 103.5 (C-6), 56.1 (7-Me), 18.7 (5-Me).

\section{Results and discussion}

The conversion reaction of ethyl acetoacetate with (un)substituted anilines 1 into corresponding acetoacetanilides 2 considered completely when ethanol formed was no longer distilled. Then, the solvent was removed entirely, and the residue consists mostly of acetoacetanilide was used to direct ring-closure into 4-methylquinolin-2(1H)-ones 3 without isolation. We found that the use of concentrated (98\%) sulfuric acid was not suitable for this cyclizing reaction due to no product was obtained or the reaction yields were very low. The concentration of sulfuric acid was $>80 \%$ also show that the results are not satisfactory. Through a survey about the influence of the concentrations of sulfuric acid to obtain the satisfied yields of 4-methylquinolin-2(1H)-one, we found that concentrations of sulfuric acid around $70-72 \%$ to be the most appropriate for the above conversion of acetoacetanilides to corresponding 4-methylquinolin-2(1H)-ones. The lower concentrations of sulfuric acid did not promote this reaction (Scheme 1).

IR spectra of these quinolines 3 had some characteristic absoption bands, such as 3454-3341 $\mathrm{cm}^{-1} \quad\left(v_{\mathrm{NH} \text { lactam }}\right), 1537 \mathrm{~cm}^{-1}$ $\left(\delta_{\mathrm{NH} \_ \text {lactam }}\right), 1657 \mathrm{~cm}^{-1}\left(v_{\mathrm{C}=\mathrm{O} \_ \text {lactam }}\right)$. In ${ }^{1} \mathrm{H}$ NMR spectra, chemical shift was in region of $11.60-11.40 \mathrm{ppm}$ belonging to $\mathrm{NH}$ bond in lactam. Carbon atom in carbonyl had resonance signals at $\delta=160-150 \mathrm{ppm}$. We found that some of substituted 4-methylquinolin-2(1H)-ones (3e and $3 \mathrm{~h}$ ) showed the existence of amide-iminol tautomerism below:

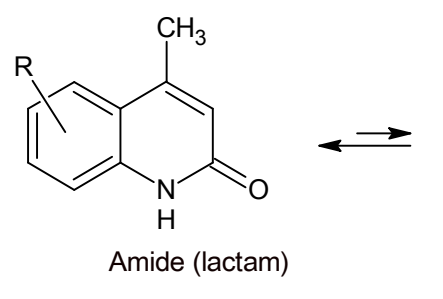<smiles>[R]c1ccc2nc(O)cc(C)c2c1</smiles>

Amide tautomer was characterized by ${ }^{1} \mathrm{H}$ NMR signals of the $\mathrm{NH}$ (lactam) bond at $\delta=8.07$ ppm, and $\mathrm{C}=\mathrm{O}($ lactam $)$ at $\delta=153.6 \mathrm{ppm}$, 
meanwhile, iminol tautomer had chemical shift at $\delta=12.17 \mathrm{ppm}(\mathrm{OH}$ phenol type), and the signal of $\mathrm{C}-2$ carbon atom moved about more upfield, $\delta=148.7 \mathrm{ppm}$.

In order to convert 4-methyl-quinoline$2(1 H)$-ones 3 to the chloro derivatives $4 \mathrm{a}-\mathrm{d}$, respectively, the former was allowed to react with $\mathrm{POCl}_{3}$ at temperatures of $70-90^{\circ} \mathrm{C}$ (Scheme 2). The reaction yields were $86-90 \%$. IR spectra of 2-chloro-4-methylquinolines 4 had some characteristic absoption bands, such as $3057-3120 \mathrm{~cm}^{-1}\left(v_{\mathrm{C}_{-} \mathrm{H}_{-}}\right.$quinoline $), 763 \mathrm{~cm}^{-1}$ $\left(v_{\mathrm{C}-\mathrm{Cl}}\right), 1530-1660 \mathrm{~cm}^{-1}\left(v_{\mathrm{C}=\mathrm{C} \_ \text {aromatic }}\right) .{ }^{1} \mathrm{H}$ NMR spectra of 2-chloro-4-methylquinolines 4 had two regions of signals: aromatic $(\delta=8.0-7.0$ ppm) and aliphatic $(\delta=\sim 2.7 \mathrm{ppm})$. ESI-MS of 4a, for example, had two peaks which had $\mathrm{m} / \mathrm{z}$ 178 and $\mathrm{m} / \mathrm{z} 180$, with relative intensities at $31 \%$ and $100 \%$, relative to the two pseudomaloecular ions $[\mathrm{M}+\mathrm{H}]^{+}$and $[\mathrm{M}+\mathrm{H}+2]^{+}$, respectively. This event was according to the presence of one chlorine atom in molecule $4 \mathrm{a}$.

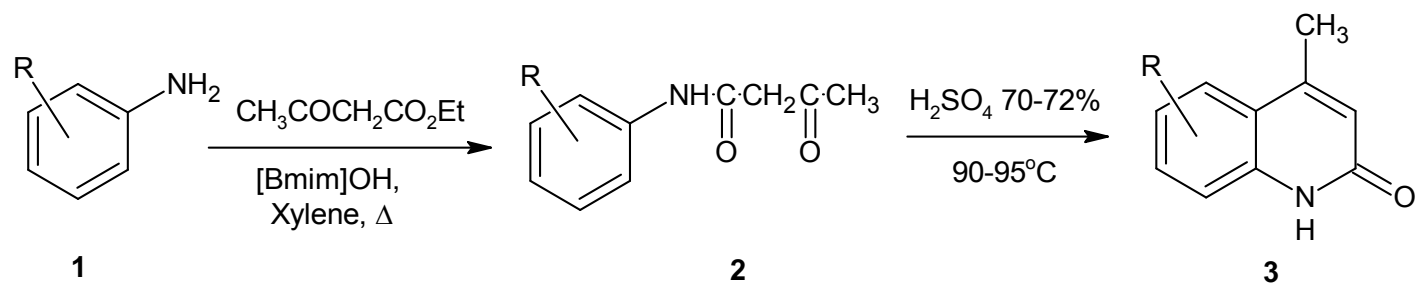

Scheme 1. Synthesis of substituted 4-methylquinolin-2(1H)-ones, where, $\mathrm{R}=\mathrm{H}(\mathbf{a}), 6-\mathrm{CH}_{3}(\mathbf{b}), 7-\mathrm{CH}_{3}(\mathbf{c}), 8-\mathrm{CH}_{3}$ (d), 6,8-- $\mathrm{diCH}_{3}(\mathbf{e}), 6-\mathrm{OCH}_{3}(\mathbf{f}), 7-\mathrm{OCH}_{3}(\mathbf{g}), 6-\mathrm{O} \mathrm{C}_{2} \mathrm{H}_{5}$ (h).

Next, substituted 2-chloro-4methylquinolines 4 was allowed to react with sodium azide in DMF. Reaction proceeded at $70^{\circ} \mathrm{C}$. We found that reactions of the 4-chloro2-methylquinolines with sodium azide gave general the corresponding 4-azido-2- methylquinolines [6], whereas the reaction of 2chloro-4-methylquinolines with sodium azide did not normally lead to the corresponding azido derivatives, but azido intermediates $\mathbf{5}^{\prime}$ ring-closured intramolecularly into fused-ring system of tetrazolo [1,5-a]quinoline $\mathbf{5}$ (Scheme 2).

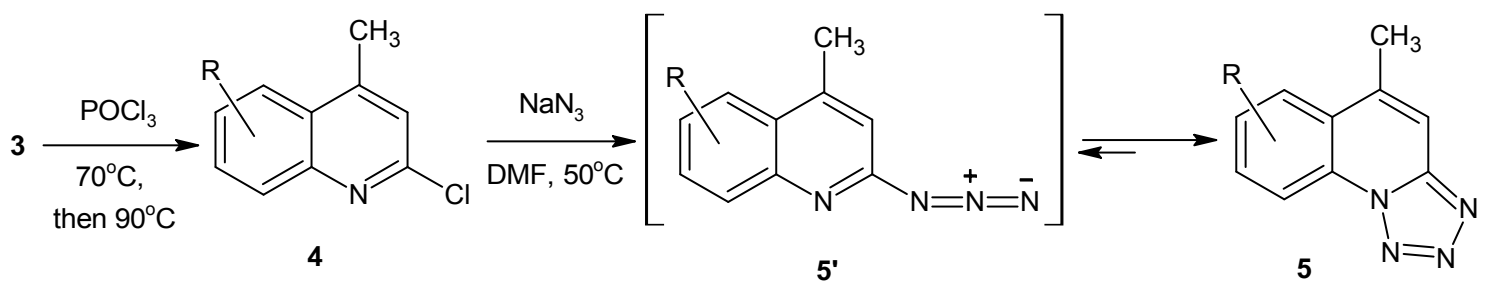

Scheme 2. Conversion of substituted 4-methylquinolin-2(1H)-ones to corresponding (un)substituted 5methyltetrazolo[1,5-a]quinolines, where, $\mathrm{R}=\mathrm{H}(\mathbf{a}), 6-\mathrm{CH}_{3}(\mathbf{b}), 7-\mathrm{CH}_{3}(\mathbf{c}), 8-\mathrm{CH}_{3}(\mathbf{d}), 6,8-\mathrm{diCH}_{3}(\mathbf{e}), 6-\mathrm{OCH}_{3}(\mathbf{f})$.

The conversion of 2-chloro-4methylquinolines to tetrazolo[1,5-a]quinolines through corresponding 2-azido-4methylquinolines was performed with DMF as solvent. This solvent helps dissolved the compound 2-chloroquinolines as well as sodium azide to facilitate the reaction. After the reaction, the tetrazolo[1,5-a]quinolines were deep yellow solid, have high melting temperature, soluble in DMF and DMSO, and slightly soluble in ethanol and methanol.

The IR spectra of all tetrazolo[1,5a]quinolines 5 showed no absorption band in the region of $2200-2100 \mathrm{~cm}^{-1}$ of azido group. 
This indicated that the 2-azido compounds did not exist, but instead of the fused heterocycle, namely tetrazolo[1,5- $a]$ quinoline. The typical signal for all protons of the compound 5 appeared in ${ }^{1} \mathrm{H}$ NMR spectra. Methyl group in the position 5 on the quinoline ring component had chemical shift in the upfield region at $\delta$ $=\sim 2.75 \mathrm{ppm}$ (as singlet). The signals located in the downfield region at $\delta=8.7-7.4 \mathrm{ppm}$ belonged to four protons of tetrazolo[1,5a]quinoline. Proton H-4 had a chemical shift at $\delta=7.96 \mathrm{ppm}$ in singlet in 5a. Resonance signal of proton H-6 was downfield at $\delta=8.63 \mathrm{ppm}$ as doublet with the coupling constant of $J=8.0 \mathrm{~Hz}$. Chemical shift at $\delta=8.84 \mathrm{ppm}$ belonged to proton $\mathrm{H}-9$ as doublet with $J=7.5 \mathrm{~Hz}$. Multiplet signal in region at $\delta=7.99-7.98 \mathrm{ppm}$ belonged to the proton $\mathrm{H}-8$; Meanwhile, proton $\mathrm{H}-7$ had resonance at $\delta=7.85 \mathrm{ppm}$ as triplet with $J=7.25$ $\mathrm{Hz}$. Amongst the protons in benzene component of quinoline ring, this proton had a resonance in the strongest field.

\section{Conclusion}

The Knorr cyclization of (un)substituted acetoacetanides have been performed through acetoacetanilides in a one-pot reaction by using ionic liquid $[\mathrm{Bmim}] \mathrm{OH}$ as catalyst from substituted anilines and ethyl acetoactate. Some obtained substituted 4-methylquinolin-2(1H)ones have been converted to tetrazolo[1,5- a]quinoline via chloro derivatives. Their structures were confirmed by IR, NMR and MS methods.

\section{References}

[1] Heeb S., Fletcher M.P., Chhabra S.R., Diggle S.P., Williams P., Cámara M., "Quinolones: from antibiotics to autoinducers", FEMS Microbiology Reviews, 35(2), (2011) 247.

[2] Acar J.F., Goldstein F.W. "Trends in bacterial resistance to fluoroquinolones", Clinical Infectious Diseases, 24 (Suppl. 1), (1997) S67.

[3] Ismail M.M., Abass M. and Hassan M.M. "Chemistry of Substituted Quinolinones. Part VI. $\dagger$ Synthesis and Nucleophilic Reactions of 4Chloro-8-methylquinolin-2(1H)-one and its Thione Analogue", 5, (2000) 1224.

[4] Welton T., "Room-Temperature Ionic Liquids. Solvents for Synthesis and Catalysis", Chemical Reviews, 99, (1999) 2071.

[5] Nguyen Dinh Thanh, Le The Hoai, Nguyen Thi Kim Giang and Nguyen Van Quoc, "Ionic Liquids as Catalyst for Synthesis of Some Aromatic Peracetylated N-( $\beta$-DGlucopyranosyl)Thiosemicarbazones", Current Organic Synthesis, 13(5), (2016) 767.

[6] Le The Duan, Nguyen Dinh Thanh, Tran Thi Thanh Van, Luu Son Quy, Doan Thi Hien, Pham Thi Anh, "Study on synthesis of some substituted 4-azido-2-methylquinolines from 4-hydroxy-2methyl-4-(1H)-quinolin-4-ones", Vietnam Jourrnal of Chemistry, 2E (55), (2017) 161. 


\title{
Nghiên cứu tổng hợp và chuyển hoá một số các 4-methylquinolin-2(1H)-on thế
}

\author{
Lê Thế Duẩn ${ }^{1}$, Nguyễn Đình Thành ${ }^{2}$, \\ Nguyễn Thị Thanh ${ }^{2}$, Hoàng Thái Vũ², Nguyễn Thị Minh Nguyệt ${ }^{2}$, \\ Lê Thị Hoài ${ }^{2}$, Nguyễn Thị Thu Hàㄹ Trần Thị Thanh Vân ${ }^{2}$ \\ ${ }^{1}$ Truò̀ng THPT Chuyên, Truò̀ng Đại họ Khoa học Tư nhiên, ĐHQGHN, \\ 182 Luoong Thế Vinh, Hà Nội, Việt Nam
}

${ }^{2}$ Khoa Hóa họ, Truò̀ng Đại học Khoa học Tụ nhiên, ĐHQGHN, 19 Lê Thánh Tông, Hà Nội, Việt Nam

Tóm tắt: Một số hợp chất 4-methylquinolin-2(1H)-on thế khác nhau đã được tổng hợp bằng cách vòng hóa các acetoacetanilide thế tương ứng khi có mặt của chất lỏng ion $[\mathrm{Bmim}] \mathrm{OH}$. Các quinoline đã tổng hợp được chuyển hoá tiếp thành dẫn xuất chloro tương ứng bằng phản ứng với $\mathrm{POCl}_{3}$. Một số hợp chất tetrazolo[1,5-a]quinolin thế đã nhận được bằng phản ứng của dẫn xuất chloro này với natri azide trong DMF. Cấu trúc của các hợp chất đã tổng hợp được xác nhận bằng các phương pháp phổ (IR, NMR và MS).

Tù khóa: Tổng hợp Knorr, 4-methylquinolin-2(1H)-on, chất lỏng ion, natri azide. 